\title{
Calcium stimulates parathyroid hormone-related protein production in Leydig tumor cells through a putative cation-sensing mechanism
}

\author{
Nicolas Buchs, Danielle Manen, Jean-Philippe Bonjour and René Rizzoli \\ Division of Bone Diseases, WHO Collaborating Center for Osteoporosis and Bone Diseases, Department of Internal Medicine, \\ University Hospital of Geneva, 1211 Geneva 14, Switzerland \\ (Correspondence should be addressed to R Rizzoli; Email: rizzoli@cmu.unige.ch)
}

\begin{abstract}
The production of parathyroid hormone-related protein (PTHrP) is regulated by a variety of hormones and growth factors. Previous research has shown that several PTHrP-producing cells are influenced by extracellular calcium $\left(\mathrm{Ca}_{\mathrm{o}}^{2+}\right)$ concentration, with elevated levels increasing PTH-like activity released by cultured $\mathrm{H} 500$ rat Leydig tumor cells through a post-transcriptional mechanism. We have investigated the hypothesis that calcium stimulates PTHrP production in $\mathrm{H} 500$ cells by interacting with a cell membrane-associated cation-sensing receptor. Besides increased $\mathrm{Ca}_{0}^{2+}$ concentration, magnesium and the polycationic antibiotic neomycin also increased PTHrP production in a concentration-dependent manner. In the presence of the calcium ionophore, ionomycin, which markedly elevated cytosolic free calcium, the stimulation by $\mathrm{Ca}_{0}^{2+}$ of PTHrP could still be detected. These results indicate that increasing $\mathrm{Ca}_{\mathrm{o}}^{2+}$ stimulates PTHrP production, possibly through a putative cell membrane-associated calcium-sensing mechanism. RT-PCR revealed the presence of a very small amount of calcium-sensing receptor coding mRNA.
\end{abstract}

European Journal of Endocrinology 142 500-505

\section{Introduction}

Parathyroid hormone-related protein (PTHrP) is recognized as a major mediator of hypercalcemia of malignancy. Apart from its effect on the renal tubular reabsorption of calcium, it increases bone resorption in the vicinity of the cancer cells (for review see 1). More recently, its crucial role in normal bone development and growth has been described (2). PTHrP is expressed in numerous tissues and its production is controlled by a large variety of hormones, growth factors, or cytokines, in a tissue-specific manner (3-5). In certain cell types, elevated extracellular calcium concentrations $\left(\mathrm{Ca}_{\mathrm{o}}^{2+}\right)$ have been reported to positively influence PTHrP production (6-9). It is increasingly recognized that calcium regulates cell proliferation and function in many cell systems (10-12). Various extracellular cation-sensing mechanisms are located in the cell membrane (13-16), which could be involved in these calcium-triggered processes. In a previous study (6), we reported that in rat Leydig tumor cells, an experimental model of humoral hypercalcemia of malignancy, an increase in $\mathrm{Ca}_{\mathrm{o}}^{2+}$ concentration stimulated PTHrP production in a de novo protein synthesis-dependent manner, apparently through a post-transcriptional process. In the present study, we extended this observation and provide evidence that the effects of $\mathrm{Ca}_{\mathrm{o}}^{2+}$ on PTHrP production involve a putative cell membrane-associated calciumsensing mechanism.

\section{Materials and methods}

\section{Cell culture}

Mice H-500 Leydig tumor cells were propagated in RPMI-1640 medium containing 10\% fetal calf serum (FCS), $100 \mathrm{IU} / \mathrm{ml}$ penicillin, and $100 \mu \mathrm{g} / \mathrm{ml}$ streptomycin. Confluent cells were split 1/10 twice a week. On day 3 in culture, media were replaced with fresh $10 \%$ FCS RPMI-1640 medium. On day 4 in culture, the monolayers were rinsed with phosphate-buffered saline and supplemented with calcium-free Dulbecco's modified Eagle's medium containing 1\% FCS, adjusted to the different cation concentrations by the addition of an appropriate amount of calcium or magnesium chloride. Incubation in the same medium was continued for $16 \mathrm{~h}$, unless otherwise indicated. Conditioned media (CM) were collected, centrifuged at $1000 \mathrm{~g}$ for $10 \mathrm{~min}$ to remove cell debris and stored at $-80^{\circ} \mathrm{C}$.

\section{Radioimmunoassay}

Immunoreactive PTHrP was measured in 1\% FCScontaining $\mathrm{CM}$ by competitive RIA performed under 
non-equilibrium conditions as follows: $100 \mu \mathrm{l} \mathrm{CM}$ or $100 \mu \mathrm{l}$ synthetic human PTHrP(1-34) standard (Auspep Inc., Melbourne, Australia) in 1\% FCS culture medium, and $100 \mu \mathrm{l}$ barbital-acetate buffer, $\mathrm{pH} 8.6$, containing $0.1 \%$ bovine serum albumin (RIA grade; Sigma Co., St Louis, MO, USA) were incubated with $100 \mu \mathrm{l}$ rabbit antihuman PTHrP(1-34) antibodies (Peninsula, Belmont, CA, USA) in duplicate at $4{ }^{\circ} \mathrm{C}$ for $24 \mathrm{~h}$. Synthetic PTHrP(1-34) was radiolabeled by a chloramine-T procedure and purified on C18 Sep-Pak cartridge columns (Waters Associates, Milford, MA, USA). Approximately 10000 c.p.m. of the radiolabeled tracer were then added for an additional $24 \mathrm{~h}$ at $4^{\circ} \mathrm{C}$. Sheep antirabbit IgG antiserum was used for the separation of the bound and free fractions. Under these conditions the detection limit was $2 \mathrm{pg}$ PTHrP/tube, non-specific binding was less than $2.0 \%$, and halfmaximal displacement occurred with about $20 \mathrm{pg} /$ tube (3). One per cent of FCS-containing unconditioned medium did not displace the bound tracer.

\section{Measurement of cytosolic free calcium}

Cells were grown on glass coverslips and loaded with a fluorescent calcium-sensing indicator by incubation with $2 \mathrm{mM}$ fura-2 acetoxy methyl ester (Calbiochem, Lucerne, Switzerland) for $30 \mathrm{~min}$ at $37^{\circ} \mathrm{C}$ in RPMI medium with 5\% FCS. Subsequently, cells were washed with the same medium. Experiments were carried out in $3 \mathrm{ml}$ of a medium containing $140 \mathrm{mM} \mathrm{NaCl}, 5 \mathrm{mM} \mathrm{KCl}$, $1 \mathrm{~g} / \mathrm{l}$ dextrose, $1 \mathrm{mM} \mathrm{Na} \mathrm{HPO}_{4} \cdot 2 \mathrm{H}_{2} \mathrm{O}, 0.4 \mathrm{mM} \mathrm{CaCl}{ }_{2}$, $20 \mathrm{mM}$ HEPES, $1 \mathrm{mM} \mathrm{MgSO} \mathrm{m}_{4} .7 \mathrm{H}_{2} \mathrm{O}$, pH 7.55, in which two to four coverslips were suspended. Fluorescence emission was recorded at $505 \mathrm{~nm}$ using an excitation wavelength of $350 \mathrm{~nm}$. Calibration of fluorescence signals (F) was performed by using $1 \mu \mathrm{M}$ ionomycin (Calbiochem) to saturate the dye with $\mathrm{Ca}^{2+}\left(\mathrm{F}_{\max }\right)$, and then quenched by the addition of $1 \mathrm{mM} \mathrm{MnCl} 2\left(\mathrm{~F}_{\min }\right)$ (17). Calculations of cytosolic free calcium $\left(\mathrm{Ca}_{\mathrm{i}}^{2+}\right)$ were carried out according to the following equation: $224 \times$ $\left(\left(\mathrm{F}-\mathrm{F}_{\min }\right) /\left(\mathrm{F}_{\max }-\mathrm{F}\right)\right)(18)$.

\section{RNA extraction and Northern blot analysis}

Total RNA was extracted from confluent rat $\mathrm{H} 500$ Leydig cells and from human parathyroid gland by the guanidine thiocyanate method as previously described (19). Subsequently, mRNA was purified using Gibco polydT columns (Gibco-BRL, Basel, Switzerland) according to the manufacturer's recommendations. Total RNA used in RT-PCR experiments was isolated from confluent rat H500 Leydig cells using Qiagen Rneasy total RNA kit (Qiagen, Basel, Switzerland). The PTHrP antisense RNA probe was labeled with $\left[\alpha^{32} \mathrm{P}\right] \mathrm{UTP}$ by in vitro transcription of the PTHrP cDNA using $\mathrm{T} 7$ polymerase (Boehringer-Mannheim, Lucerne, Switzerland). Northern blot analysis was performed with $1 \mu \mathrm{g}$ mRNA denatured in glyoxal, electrophoresed in $1.5 \%$ agarose gel and transferred overnight onto nylon filters (Hybond-N; Amersham International plc, Amersham, Bucks, UK). The filters were baked at $80^{\circ} \mathrm{C}$ for $2 \mathrm{~h}$, and hybridized with the RNA probe. Prehybridization $(3 \mathrm{~h})$ and hybridization (overnight) were carried out at $65^{\circ} \mathrm{C}$ in $50 \%$ formamide, $1 \times$ Denhardt's solution, $50 \mathrm{mM}$ PIPES, 0.8 M NaCl, 2 mM EDTA, 01\% SDS, and 100 $\mu \mathrm{g} /$ $\mathrm{ml}$ denatured herring sperm DNA. The blots were washed twice for $20 \mathrm{~min}$ at $65^{\circ} \mathrm{C}$ in $3 \times \mathrm{SSC}, 2 \times$ Denhardt's solution, and then twice for $20 \mathrm{~min}$ at $70{ }^{\circ} \mathrm{C}$ in $0.2 \times \mathrm{SSC}, 0.1 \mathrm{SDS}$, and $01 \% \mathrm{NaPPi}$. After immersion in $1 \%$ SDS at $95^{\circ} \mathrm{C}$, the same filters were rehybridized with BamHI fragment of the human cyclophylin probe as control (20).

\section{RT-PCR and PCR}

RT-PCR was performed using the Titan One Tube RTPCR kit from Boehringer-Mannheim following the supplier's recommendations. RNA template $(1 \mu \mathrm{g})$ was extracted from the rat H500 Leydig cells, and from human parathyroid gland, as a positive control, for the detection of the calcium-sensing receptor (CaR). Primers used for RT-PCR were N1F: GCTTTGAGTGTGTGGAGTGTGTCC, and N2R: ATCTGCATGAAGGTGCAGAGG. Taking into account the homology between human and rat CaR cDNAs, these primers were designed to detect both human and rat cDNA (human CaR mRNA, accession number, U20760; Rattus norvegicus kidney CaR mRNA, accession number, U10354). This set of primers span one intron of the CaR gene (21). For the purpose of a second round of PCR, we used the nested primer pairs N3F: CTGCTCCAATGAGAACCACAC, and N4R: CAGCAGGAACTGCAGGTTGAG. PCR reaction was carried out in $50 \mu \mathrm{l}$ using Qiagen Taq DNA polymerase (Qiagen). Temperature cycling protocol was $94^{\circ} \mathrm{C}$ for $30 \mathrm{~s}, 55^{\circ} \mathrm{C}$ for $30 \mathrm{~s}, 72^{\circ} \mathrm{C}$ for $1 \mathrm{~min}$, for 30 cycles. The reaction was concluded with a 10-min elongation at $72{ }^{\circ} \mathrm{C}$. Ten microliters of the RT-PCR and PCR products were fractionated on a $1.2 \%$ agarose gel. An automated DNA sequencer (Perkin Elmer 310) was used for sequence analysis.

\section{Other methods}

PTHrP production was corrected for total cell protein, using the method of Lowry (22). $\mathrm{Ca}_{\mathrm{i}}^{2+}$ levels were modulated by using either the calcium ionophore ionomycin, or chelators such as BAPTA/AM (1,2-bis (o-aminophenoxy)ethane-N,N, $\mathrm{N}^{\prime}, \mathrm{N}^{\prime}$,-tetraacetic acid tetra(acetoxymethyl) ester) (23), or Quin-2/AM (23, 24). All these reagents were from Calbiochem. As phorbol myristate acetate (PMA), they were dissolved in dimethyl-sulfoxide, the latter at a final concentration of $0.1 \%$.

\section{Statistical analysis}

Results are means \pm S.E.M. of separate experiments, all performed in at least triplicate. Significance of differences 
was evaluated using an analysis of variance, with Bonferroni's criterion for multiple comparison.

\section{Results}

\section{Effects of cations on PTHrP production}

Increasing concentrations of $\mathrm{Ca}_{o}^{2+}$ or magnesium were associated with an increment of immunoreactive PTHrP released into the culture medium (Fig. 1). To evaluate whether the cation-sensitive PTHrP-stimulating mechanism was also influenced by polycations, we examined the effects of the antibiotic neomycin (25). Neomycin mimicked the effects of calcium on PTHrP release and it appeared to potentiate the stimulation caused by $\mathrm{Ca}_{0}^{2+}$ (Fig. 2).

\section{$\mathrm{Ca}_{\mathrm{i}}^{2+}$ and PTHrP production}

We investigated changes in $\mathrm{Ca}_{\mathrm{i}}^{2+}$ in response to an increase in the concentration of $\mathrm{Ca}_{\mathrm{o}}^{2+}$ under conditions where PTHrP was consistently stimulated. The acute increment from 0.4 to $3.0 \mathrm{mM}$ was associated with a transient increase of $\mathrm{Ca}_{\mathrm{i}}^{2+}$ of $30 \%$ (from $140 \pm 17$ to $212 \pm 34 \mathrm{nM}, P<0.05, n=12$ separate experiments). To evaluate whether high magnitude modifications of $\mathrm{Ca}_{\mathrm{i}}^{2+}$ could alter PTHrP release, Leydig tumor cells were incubated for varying periods of time with $1 \mu \mathrm{M}$

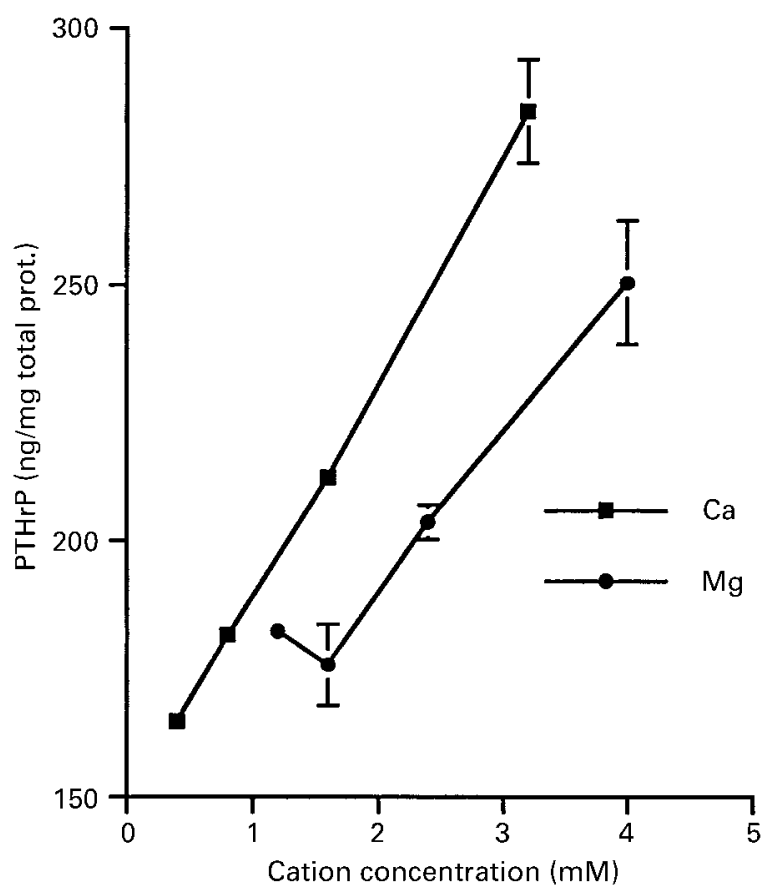

Figure 1 Effects of increasing concentrations of calcium or magnesium on PTHrP production in cultured Leydig tumor cells. On day 3 after seeding, cells were incubated with varying concentrations of the cations for $16 \mathrm{~h}$. The medium was assayed for PTHrP released. The results are expressed as $\mathrm{pg} P \mathrm{PHrP}(1-34) / \mathrm{mg}$ cell protein and are the means \pm S.E.M. of four replicates.

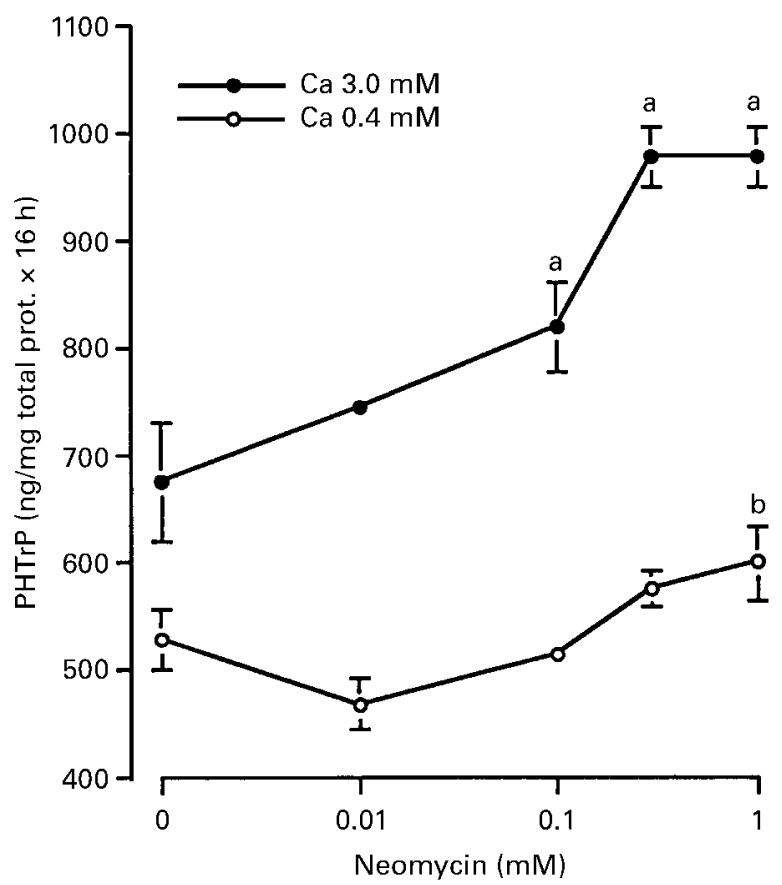

Figure 2 Effects of neomycin on PTHrP production. On day 3 after seeding, cells were incubated with increasing concentrations of neomycin, in the presence of 0.4 or $3.0 \mathrm{mM}$ calcium, for $16 \mathrm{~h}$. The medium was assayed for $\mathrm{PTHrP}$ released. The results are expressed as pg PTHrP(1-34)/mg cell protein and are the means \pm S.E.M. of four replicates. Effect of neomycin: $P=0.0007$ and $P=0.0001$ for 0.4 and $3.0 \mathrm{mM}$ calcium respectively. ${ }^{\mathrm{a}} P<0.05$ as compared with no addition of neomycin; ${ }^{b} P<0.05$ as compared with $0.01 \mathrm{mM}$ neomycin. All the values in the $3.0 \mathrm{mM}$ calcium curve significantly differed from the $0.4 \mathrm{mM}$ one.

ionomycin, which dissipates the extra/intracellular calcium gradient $(26,27)$. Under these conditions, increasing concentrations of $\mathrm{Ca}_{\mathrm{o}}^{2+}$ still caused a concentration-dependent increment of PTHrP production (Fig. 3). These experiments suggested that changes in $\mathrm{Ca}_{\mathrm{o}}^{2+}$ concentration may influence PTHrP production, independently of $\mathrm{Ca}_{\mathrm{i}}^{2+}$ concentration. Conversely, in an attempt to trap the $\mathrm{Ca}_{\mathrm{i}}^{2+}$ we used the calcium chelators BAPTA/AM and Quin-2/AM, but no modification of the calcium-stimulated PTHrP production was observed (Table 1).

\section{Effects of protein kinase C (PKC) stimulation by PMA on the calcium-dependent change of PTHrP production}

To investigate whether the PKC signal transduction pathway was involved in calcium-stimulated PTHrP production, we tested the effect of PMA. Leydig tumor cells were incubated for $16 \mathrm{~h}$ with $0.1 \mathrm{mM}$ of the phorbol ester PMA. The effects of $3.0 \mathrm{mM}$ calcium as compared with $0.4 \mathrm{mM}$ on PTHrP release were not modified by PMA $(+172 \pm 7 \%$ in controls and $+174 \pm 15 \%$ in PMA-treated cells), but PMA was associated with higher levels of PTHrP mRNA (Fig. 4). Similarly, the response to 


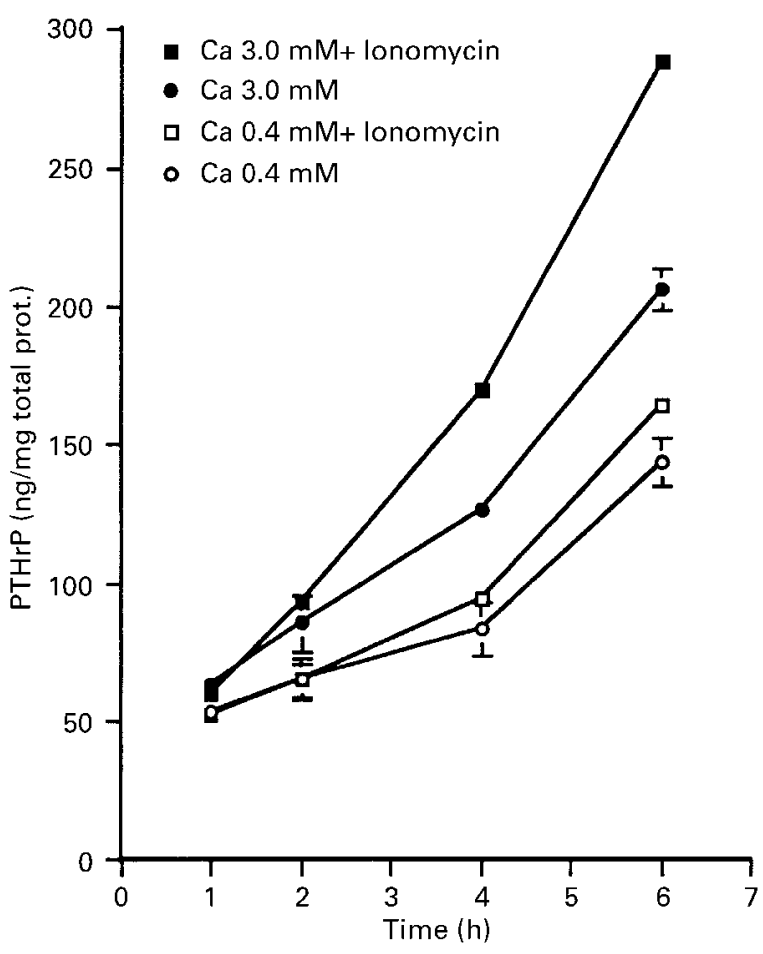

Figure 3 Effects of the calcium ionophore ionomycin on PTHrP production. On day 3 after seeding, cells were incubated in the presence of 0.4 or $3.0 \mathrm{mM}$ calcium, with or without $1 \mu \mathrm{M}$ ionomycin, for various periods of time. The medium was assayed for PTHrP. The results are expressed as pg PTHrP(1-34)/mg cell protein and are the means \pm S.E.M. of triplicates.

calcium was not altered in the presence of the PKC inhibitor staurosporine (data not shown). In contrast, as previously suggested, $\mathrm{Ca}_{0}^{2+}$ increased PTHrP production without changes in mRNA, irrespective of PMA treatment.

\section{Search for a CaR in cultured Leydig tumor cells}

Using RT-PCR analysis, we searched for the presence of the extracellular CaR, which has been characterized in

Table 1 Effects of extracellular calcium on PTHrP production in the presence of modulators of cytosolic free calcium concentration. Culture medium was conditioned with Leydig tumor cells for $16 \mathrm{~h}$ in the presence of $0.4 \mathrm{mM}$ or $3.0 \mathrm{mM}$ extracellular calcium, and the various modulators. Number of experiments (each experiment included triplicates) in parentheses.

\begin{tabular}{lcc}
\hline & \multicolumn{2}{c}{ PTHrP production (\%) } \\
\cline { 2 - 3 } & $0.4 \mathrm{mM} \mathrm{Ca}_{0}^{2+}$ & $3.0 \mathrm{mM} \mathrm{Ca}_{0}^{2+}$ \\
\hline Controls $(22)$ & 100 & $172 \pm 7^{*}$ \\
lonomycin $(1 \mu \mathrm{M})(4)$ & 100 & $203 \pm 23^{*}$ \\
BAPTA/AM $(25 \mu \mathrm{M})(2)$ & 100 & $189 \pm 22^{\star}$ \\
BAPTA/AM $(50 \mu \mathrm{M})(2)$ & 100 & $189 \pm 47^{\star}$ \\
Quin-2/AM $(10 \mu \mathrm{M})(2)$ & 100 & $152 \pm 12^{*}$ \\
\hline
\end{tabular}

${ }^{*} P<0.05$.
PTHrP MRNA

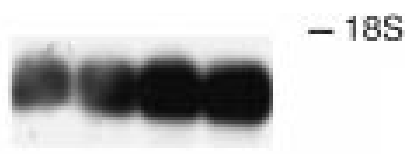

Cyclophylin mRNA

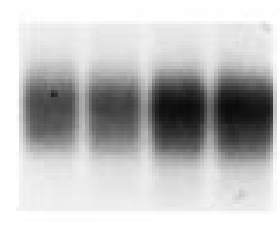

Calcium (mM)

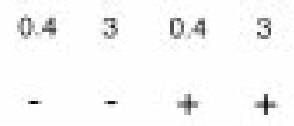

PMA

Figure 4 Northern blot analysis of poly $\mathrm{A}^{+} \mathrm{RNA}(1 \mu \mathrm{g} /$ lane) isolated from Leydig tumor cells incubated for $16 \mathrm{~h}$ with 0.4 or $3.0 \mathrm{mM}$ calcium in the presence or absence of PMA (see cell culture in Materials and methods).

parathyroid cells (13). No amplified product was detected from $1 \mu \mathrm{g}$ Leydig tumor cell total RNA unlike that from human parathyroid total RNA (Fig. 5). A second round of PCR with nested primer-amplified products which were found to be $100 \%$ homologous to the $\mathrm{CaR}$ was carried out (Fig. 5, lane 4). These results indicate the presence of a very small amount of $\mathrm{CaR}$ mRNA in the Leydig tumor cells.

\section{Discussion}

We previously reported that the production of PTHrP in rat Leydig tumor cells was augmented by increased $\mathrm{Ca}_{0}^{2+}(6)$. In the present work, we have confirmed that calcium stimulation of PTHrP production in Leydig tumor cells acts at a post-transcriptional level. Furthermore, we have provided evidence that the $\mathrm{Ca}_{0}^{2+}$ effect on PTHrP production is poorly correlated with changes in the $\mathrm{Ca}_{\mathrm{i}}^{2+}$ concentration and seems to implicate a cell membrane-sensitive mechanism. Indeed, the response was not specific to calcium, since other divalent cations such as magnesium and the polycationic antibiotic neomycin also stimulated PTHrP production. The response to magnesium was similar to the calcium
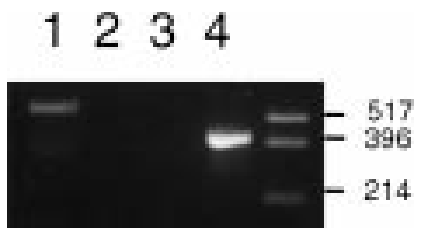

Figure 5 RT-PCR analysis of CaR RNA from rat H500 Leydig cells. Amplification and analysis were carried out as specified in the Materials and methods section. Lane 1, positive control, RT-PCR carried out on parathyroid RNA with the primer pair N1F-N2R; lanes 2 and 3, RT-PCR carried out on Leydig tumor cells RNA with the primer pairs N1F-N2R and N3F-N4R respectively; lane 4, amplification of the RT-PCR shown in lane 2 with the nested primer pair N3F-N4R. 
response, with neomycin mimicking the calcium effect but to a lesser extent. The effect was markedly enhanced in the presence of a high concentration of calcium.

We then evaluated the modulation of $\mathrm{Ca}_{i}^{2+}$ response to changes in $\mathrm{Ca}_{\mathrm{O}}^{2+}$ concentrations. The alteration in $\mathrm{Ca}_{\mathrm{i}}^{2+}$ was minimal and transient. Furthermore, to evaluate if a change in the $\mathrm{Ca}_{\mathrm{i}}^{2+}$ concentration modified the PTHrP release, we treated the cells with the ionophore ionomycin, which dissipates the extra/intracellular calcium gradient. Under these conditions, the production of PTHrP was still stimulated by the increment of calcium in the medium. This finding suggests that the increase of $\mathrm{Ca}_{\mathrm{i}}^{2+}$ concentration was insufficient to account for the response to $\mathrm{Ca}_{\mathrm{o}}^{2+}$ changes in terms of PTHrP release. Moreover, we showed that chelators of $\mathrm{Ca}_{\mathrm{i}}^{2+}$, such as BAPTA/AM or Quin-2/AM, did not modify the response to $3 \mathrm{mM} \mathrm{Ca}_{\mathrm{o}}^{2+}$.

All these results suggest that the effect of calcium could be mediated by a membrane calcium-sensing mechanism. The most extensively studied example of calcium-sensing receptor is that present in parathyroid cells (CaR) and which regulates PTH secretion in response to changes in $\mathrm{Ca}_{0}^{2+}$ concentration (28). CaR has also been identified in kidney (29), brain (30), keratinocytes (31), and other tissues including thyroid $\mathrm{C}$ cells $(28,32)$. CaR is a transmembrane calcium-sensing receptor coupled to $\mathrm{G}$ protein, the stimulation of which results in an inhibition of cAMP synthesis, a stimulation of phospholipase $\mathrm{C}$ and of inositol phosphate turnover, and increments in $\mathrm{Ca}_{\mathrm{i}}^{2+}$. The CaR effect is presumed to use the PKC pathway (13). Using RT-PCR, we searched for the presence of CaR mRNA, but the messenger was detected only after a second round of PCR. In addition, we found that stimulation of the PKC by PMA did not significantly change either the PTHrP release in the medium or the level of PTHrP transcription in response to increased $\mathrm{Ca}_{\mathrm{o}}^{2+}$ concentration. These results indicate the presence of a putative calcium-sensing mechanism in Leydig tumor cells. However, the small amount of $\mathrm{CaR}$ mRNA detected and the apparent independence of the PKC pathway suggests the involvement of a calciumsensing mechanism distinct from the extensively studied CaR present in the parathyroid gland $(13,28)$.

\section{Acknowledgements}

Mrs C Decrind and L Ackermann are acknowledged for their expert technical assistance. We are indebted to Dr M Aubert for the labeling of the PTHrP tracer, and to Dr JF Manen for PCR product sequencing. We thank Mrs M Perez for typing the manuscript. This work was supported by the Swiss National Science Research Fund (grant no. 32-49839.96).

\section{References}

1 Dunbar ME, Wysolmerski JJ \& Broadus AE. Parathyroid hormone-related protein: from hypercalcemia of malignancy to developmental regulatory molecule. American Journal of Medical Sciences 1996312 287-294.

2 Karaplis AC, Luz A, Glowacki J, Bronson RT, Tybulewicz VL, Kronenberg HM et al. Lethal skeletal dysplasia from targeted disruption of the parathyroid hormone-related peptide gene. Genes and Development 19948 277-289.

3 Rizzoli R, Feyen JH, Grau G, Wohlwend A, Sappino AP \& Bonjour JP. Regulation of parathyroid hormone-related protein production in a human lung squamous cell carcinoma line. Journal of Endocrinology 1994143 333-341.

4 Moseley JM \& Gillespie MT. Parathyroid hormone-related protein. Critical Reviews in Clinical Laboratory Sciences 199532 299-343.

5 Martin TJ, Moseley JM \& Williams ED. Parathyroid hormonerelated protein: hormone and cytokine. Journal of Endocrinology 1997154 S23-S37.

6 Rizzoli R \& Bonjour JP. High extracellular calcium increases the production of a parathyroid hormone-like activity by cultured Leydig tumor cells associated with humoral hypercalcemia. Journal of Bone and Mineral Research 19894 839-844.

7 Kremer R, Karaplis AC, Henderson J, Gulliver W, Banville D, Hendy GN et al. Regulation of parathyroid hormone-like peptide in cultured normal human keratinocytes. Effect of growth factors and 1,25 dihydroxyvitamin D3 on gene expression and secretion. Journal of Clinical Investigation 199187 884-893.

8 Brandt DW, Pandol SJ \& Deftos LJ. Calcium-stimulated parathyroid hormone-like protein secretion: potentiation through a protein kinase-C pathway. Endocrinology 1991128 2999-3004.

9 Henderson J, Sebag M, Rhim J, Goltzman D \& Kremer R. Dysregulation of parathyroid hormone-like peptide expression and secretion in a keratinocyte model of tumor progression. Cancer Research 199151 6521-6528.

10 Mailland M, Waelchli R, Ruat M, Boddeke HG \& Seuwen K. Stimulation of cell proliferation by calcium and a calcimimetic compound. Endocrinology 1997138 3601-3605.

11 McNeil L, Hobson S, Nipper V \& Rodland KD. Functional calciumsensing receptor expression in ovarian surface epithelial cells. American Journal of Obstetrics and Gynecology 1998178 305313.

12 McNeil SE, Hobson SA, Nipper V \& Rodland KD. Functional calcium-sensing receptors in rat fibroblasts are required for activation of SRC kinase and mitogen-activated protein kinase in response to extracellular calcium. Journal of Biological Chemistry 1998273 1114-1120.

13 Brown EM, Gamba G, Riccardi D, Lombardi M, Butters R, Kifor O et al. Cloning and characterization of an extracellular $\mathrm{Ca}(2+)-$ sensing receptor from bovine parathyroid. Nature 1993366 575-580.

14 Seuwen K, Boddeke HG, Migliaccio S, Perez M, Taranta A \& Teti A. A novel calcium sensor stimulating inositol phosphate formation and $\left[\mathrm{Ca}^{2+}\right]_{\mathrm{i}}$ signaling expressed by GCT23 osteoclast-like cells. Proceedings of the Association of American Physicians 1999111 70-81.

15 Hinson TK, Damodaran TV, Chen J, Zhang X, Qumsiyeh MB, Seldin MF et al. Identification of putative transmembrane receptor sequences homologous to the calcium-sensing G-protein-coupled receptor. Genomics 199745 279-289.

16 Lundgren S, Carling T, Hjalm G, Juhlin C, Rastad J, Pihlgren U et al. Tissue distribution of human gp330/megalin, a putative $\mathrm{Ca}(2+)$-sensing protein. Journal of Histochemistry and Cytochemistry 199745 383-392.

17 Hesketh TR, Smith GA, Moore JP, Taylor MV \& Metcalfe JC. Free cytoplasmic calcium concentration and the mitogenic stimulation of lymphocytes. Journal of Biological Chemistry 1983258 4876-4882.

18 Grynkiewicz G, Poenie M \& Tsien RY. A new generation of $\mathrm{Ca}^{2+}$ indicators with greatly improved fluorescence properties. Journal of Biological Chemistry 1985260 3440-3450.

19 Sappino AP, Busso N, Belin D \& Vassalli JD. Increase of urokinasetype plasminogen activator gene expression in human lung and breast carcinomas. Cancer Research 198747 4043-4046. 
20 Danielson PE, Forss-Petter S, Brow MA, Calavetta L, Douglass J, Milner RJ et al. p1B15: a cDNA clone of the rat mRNA encoding cyclophilin. DNA $19887261-267$.

21 Pollak MR, Brown EM, Chou YH, Hebert SC, Marx SJ, Steinmann $\mathrm{B}$ et al. Mutations in the human $\mathrm{Ca}(2+)$-sensing receptor gene cause familial hypocalciuric hypercalcemia and neonatal severe hyperparathyroidism (see comments). Cell 199375 1297-1303.

22 Lowry O. Micromethods for the assay of enzyme. II. Specific procedures. Alkaline phosphatase. Methods in Enzymology 19554 371-372.

23 Hatayama K, Kambayashi J, Nakamura K, Ohshiro T \& Mori T. Fluorescent $\mathrm{Ca}^{2+}$-indicator quin 2 as an intracellular $\mathrm{Ca}^{2+}$ antagonist in platelet reaction. Thrombosis Research 198538 505-512.

24 Pershadsingh HA, Shade DL, Delfert DM \& McDonald JM. Chelation of intracellular calcium blocks insulin action in the adipocyte. Proceedings of the National Academy of Sciences of the USA 198784 1025-1029.

25 Brown EM, Butters R, Katz C \& Kifor O. Neomycin mimics the effects of high extracellular calcium concentrations on parathyroid function in dispersed bovine parathyroid cells. Endocrinology $19911283047-3054$.

26 Wakasugi H, Kimura T, Haase W, Kribben A, Kaufmann R \& Schulz I. Calcium uptake into acini from rat pancreas: evidence for intracellular ATP-dependent calcium sequestration. Journal of Membrane Biology 198265 205-220.
27 Burgess GM, McKinney JS, Fabiato A, Leslie BA \& Putney JW Jr. Calcium pools in saponin-permeabilized guinea pig hepatocytes. Journal of Biological Chemistry 1983258 15336-15345.

28 Brown EM, Chattopadhyay N, Vassilev PM \& Hebert SC. The calcium-sensing receptor $(\mathrm{CaR})$ permits $\mathrm{Ca}^{2+}$ to function as a versatile extracellular first messenger. Recent Progress in Hormone Research 199853 257-280; discussion 280-281.

29 Riccardi D, Park J, Lee WS, Gamba G, Brown EM \& Hebert SC. Cloning and functional expression of a rat kidney extracellular calcium/polyvalent cation-sensing receptor. Proceedings of the National Academy of Sciences of the USA 199592 131-135.

30 Ruat M, Molliver ME, Snowman AM \& Snyder SH. Calcium sensing receptor: molecular cloning in rat and localization to nerve terminals. Proceedings of the National Academy of Sciences of the USA 199592 3161-3165.

31 Bikle DD. 1,25(OH) 2 D3-modulated calcium induced keratinocyte differentiation. Journal of Investigative Dermatology (Symposium Proceedings) $1996122-27$.

32 Garrett JE, Tamir H, Kifor O, Simin RT, Rogers KV, Mithal A et al. Calcitonin-secreting cells of the thyroid express an extracellular calcium receptor gene. Endocrinology 1995136 5202-5211.

Received 17 August 1999

Accepted 5 January 2000 